\title{
O estranho e o fingimento literário em "um esqueleto”, de Machado de Assis
}

\author{
Nismária Alves David Barros*
}

\section{Resumo}

Mediante a análise das relações entre o estranho e o fingimento literário, o presente trabalho revisita "Um esqueleto", de Machado de Assis. Trata-se de uma releitura com o propósito de mostrar que este conto, publicado em 1875, além de aludir a temas essenciais da condição humana, busca despertar o efeito de imprevisto mas também a co-participação do leitor para complementar a estrutura comunicativa do texto artístico e, por essas razões, recorre a recursos como, por exemplo, o lúdico, a ironia e o humor.

Palavras-chave: Estranho. Fingimento literário. Leitor. Machado de Assis.

\begin{abstract}
The present paper revisits "Um esqueleto" by Machado de Assis through analysis of the relationships between the stranger and the literary dissimulation. It is a reading with the purpose of showing that this short story, published in 1875, alludes essential themes of human condition, as well as it stimulates the effect of unexpected and the reader`s copartnership to complement the communicative structure of the artistic text. For these reasons, this short story uses resources, for example, the ludic, the irony and the humour.
\end{abstract}

Key-words: Stranger. Literary dissimulation. Reader. Machado de Assis.

\section{Considerações iniciais}

No Rio de Janeiro, em 1875, Machado de Assis complementava seus ganhos extra com a produção de contos para o Jornal das Famílias, gazeta extinta em setembro de 1878 (PIZA, 2006). Nesse periódico, de outubro a novembro de 1875, tem-se originalmente a publicação de "Um esqueleto", conto machadiano que este artigo pretende reler com o propósito de caracterizar o tratamento concedido ao estranho. Para tanto, abordar-se-á o emprego de lúdico, ironia e humor - expedientes que constituem o fingimento literário promovido pela narrativa em questão.

\footnotetext{
* Doutora em Letras e Linguística pela Universidade Federal de Goiás (UFG) e Professora de Literatura da Universidade Estadual de Goiás (UEG), Unidade Universitária de Pires do Rio. E-mail: nisdavid@yahoo.com.br
} 
Acerca das obras de ficção de Machado de Assis, considerado um dos autores mais representativos da Literatura Brasileira, inúmeros estudos já foram realizados sob distintas perspectivas teóricas. Dentre esses, vale destacar o interesse da Crítica Literária em demonstrar a repercussão de Edgar Allan Poe na escritura machadiana que apresenta o mistério, o inesperado e o insólito em contos como, por exemplo, “A visita de Alcebíades”, “A Cartomante”, “A igreja do diabo”, “A chinela turca”, "Entre Santos” e “As academias de Sião”, bem como a temática do duplo em “O espelho” e “Teoria do medalhão”.

Nesse sentido, Paul Dixon (1992), em Os contos de Machado de Assis: mais do que sonha a Filosofia, demonstra a negação dos preceitos de Auguste Comte realizada por Machado, devido a uma reivindicação do mistério inexplicável pela filosofia positivista. Para Dixon, essa atitude antecipa um espírito da fenomenologia, visto que o escritor brasileiro enfatiza sobretudo o psicológico e não o social, o metafísico e não o moral, e o autorreferencial em vez do referencial.

Outrossim, Costa Val (2000) nota que a literatura fantástica surge em direção oposta à corrente filosófica do positivismo - o qual busca explicações racionais aos fenômenos do universo - para revelar a insuficiência da ciência e da filosofia. Em seu artigo "Machado de Assis e o fantástico espelho”, aponta que o precursor do realismo fantástico na literatura brasileira, Murilo Rubião, declara em entrevista a Elizabeth Lowe: “O fantástico em nosso século, cujo maior precursor é Kafka, e aqui no Brasil é Machado de Assis, é muito diferente daquele do século XIX” (RUBIÃO, 1979 apud COSTA VAL, 2000, p. 21). Segundo a autora, trata-se de uma declaração que acaba sendo uma sugestão para se refletir sobre a historiografia da Literatura Brasileira, reavaliando a costumeira restrição ao realismo dada a Machado.

O próprio Machado de Assis, em ensaio publicado em 1879, A nova geração, embora direcionado à realidade, aponta suas críticas ao realismo como a escola mais frágil por negar o princípio da arte. Por isso, “em muitos aspectos os contos machadianos são uma glorificação do estranho e do inesperado - das singulares ocorrências, dos lapsos e das excursões milagrosas” (DIXON, 1992, p. 10). Conforme Bastos (2003, p. 32), a manifestação de um sentido de mistério ou do fantástico tenta abarcar "uma realidade que, ao tornar-se mais complexa, deixou de caber nos limites das condições sócio-históricas representadas na ficção realista”.

Nessa direção de abordagem do sobrenatural, vale destacar a pesquisa de Mestrado de Marcelo José Fonseca Fernandes (2003), intitulada Quase-macabro: o fantástico nos contos de Machado de Assis, na qual se esclarece que Machado traz um fantástico mitigado e, na 
maioria das vezes, explicável a partir da retomada de consciência da personagem. Ao fantástico mitigado ou explicável associa-se a concepção de Todorov (1975) sobre o estranho cuja manifestação ocorre em obras que relatam acontecimentos extraordinários, singulares e inquietantes, os quais podem ser esclarecidos pela lei da razão.

Tomando-se por base essa concepção e, em especial, a caracterização de obras fantásticas apresentada por Louis Vax (1987), em La séduction de létrange, proceder-se-á à análise de “Um esqueleto”.

\section{Caracterizando o estranho em "Um esqueleto".}

Dividido em seis capítulos, o conto “Um esqueleto” apresenta duas narrativas encaixadas, procedimento recorrente de Machado de Assis: a primeira, realizada nos capítulos I e VI, traz o narrador que é ora heterodiegético ora homodiegético (doravante chamado N1); a segunda, por sua vez, é oferecida pelo narrador-personagem Alberto. Ambos os narradores contam fatos ocorridos em tempos imemoriais e não indicam, de modo preciso, as localizações geográficas, recursos que contribuem para envolver o leitor numa atmosfera de mistério.

Na situação inicial, ao enunciar "Eram dez ou doze rapazes” e "Mas nenhum dos doze convivas fazia caso do mar”, N1 já sugere uma incerteza e a reitera pelo emprego do verbo parecer: "Deus me perdoe! parece que até se fizeram alguns trocadilhos” (ASSIS, 1992, p. 814, grifo nosso). Salienta-se que esses convivas, assim como no conto “O espelho” (Esboço de uma nova teoria da alma humana), de Papéis Avulsos (1882), pretendem se mostrar conhecedores de assuntos complexos (artes, letras, política), mas também se divertem com pilhérias.

Diante da caracterização do ambiente de maneira aterrorizante, por evocar uma natureza mórbida - praia solitária, noite que era feia e ameaçava chuva, meia-noite, noite escura, “o mar batia funebremente na praia”, “pleno Hoffmann” (ASSIS, 1992, p. 815) dentre os vários assuntos discutidos, N1 ressalta que os rapazes falam sobre a beleza da língua alemã quando a conversa envereda para a história de Dr. Belém. Concedida voz a Alberto, este, além de apresentar o Dr. como um homem singular, excêntrico e bastante intelectualizado, emprega a melancolia e o saudosismo para comover os ouvintes: 
- Desculpem-me este silêncio; não me posso lembrar daquele homem sem que uma lágrima teime em rebentar-me dos olhos. Era um excêntrico, talvez não fosse, não era decerto um homem completamente bom; mas era meu amigo; não direi o único mas o maior que jamais tive na minha vida. (ASSIS, 1992, p. 815).

Sobretudo, o narrador-personagem aguça a curiosidade dos presentes ao propor a narração da história do esqueleto do Dr. Belém, a qual se efetiva a partir do capítulo II do texto, conforme adianta N1: “A palavra esqueleto aguçou a curiosidade dos convivas; um romancista aplicou o ouvido para não perder nada da narração; todos esperaram ansiosamente o esqueleto do Dr. Belém. [...]” (ASSIS, 1992, p. 815).

Para discorrer sobre a criação de um halo de fantástico no texto em foco, vale reportarse à obra La séduction de l'étrange (1987), na qual Louis Vax distingue motivo e tema. Segundo o autor, o motivo é considerado o elemento central da narrativa, uma imagem que não se esgota na significação, não possui definições precisas, algo favorável à arte por ser plurissignificativa, de onde surgem temas diversos que, por sua vez, englobam o texto inteiro. Assim, embora esqueleto intitule o conto e seja o motivo que oferece o insólito na narrativa, verifica-se que, devido ele ser exibido como um mero objeto, o mistério e o sobrenatural não estão nesse elemento, mas sim nas descrições da figura e do comportamento de seu possuidor, o Dr. Belém.

Molino (1980) lembra que Vax define a literatura fantástica por seu conteúdo semântico e, nesta semântica do fantástico, há a semântica objetiva (que revela os elementos constitutivos do mundo fantástico) e a semântica subjetiva (que evoca as reações do sujeito a este mundo). Desse modo, para definir a expressividade do fantástico, Vax (1987) aponta a existência de dois procedimentos na caracterização de obras fantásticas: o primeiro refere-se ao motivo central que é a história de fantasmas; e o segundo diz respeito à impressão estranha que a obra deve causar.

Nessa segunda perspectiva, a obra fantástica deve oferecer ao leitor objetos e/ou seres estranhos que lhe podem causar angústia como, por exemplo, o pacto com o demônio apontado por Roger Caillois, o lobisomen por Peter Penzoldt, os esqueletos por Marcel Brion e histórias de doença e de loucura por Dorothy Sayers - cumpre mencionar que são motivos aludidos na descrição de Dr. Belém. Conquanto sejam insatisfatórias as classificações e vã a tentativa de estabelecer a natureza do fantástico, trata-se de motivos tradicionais que atendem a concepção de fantástico que os estudiosos mencionados possuem.

Todavia, segundo Vax (1987), a atividade artística engendra o fantástico, visto que a obra torna o motivo fantástico e gera o sentimento de estranho cuja essência consiste na própria consciência do estranho, que se recusa a reconhecer-se. Dessa forma, encontra-se esse 
sentimento, no qual repousa o fantástico, à medida que se participa de uma situação desconcertante e ameaçadora.

No conto machadiano, oferece-se ao motivo esqueleto o caráter original que obtém dele, atualiza e delimita-o, bem como se nota o desconcerto quando o narrador Alberto recorre à imaginação do povo para construir a imagem de Dr. Belém, carregando-lhe com a ilusão de ser e, aliás, sua associação com o esqueleto torna-o um motivo que estimula o sobrenatural e, até mesmo, o pavor. A referência à superstição popular é tanto desacreditada quanto valorizada, pois a criatura imaginária diverte e realiza o papel de uma autoridade, justificando o horror coletivo (VAX, 1987). Deve-se frisar, pelo exposto, os seguintes excertos do conto:

O DR. BELÉM era um homem alto e magro; tinha os cabelos grisalhos e caídos sobre os ombros; em repouso era reto como uma espingarda; quando andava curvava-se um pouco. Conquanto o seu olhar fosse muitas vezes meigo e bom, tinha lampejos sinistros, e às vezes, quando ele meditava, ficava com olhos como de defunto.

[...] Podiam contar-se-lhe três ou quatro rugas pronunciadas na cara, cuja pele era fria como o mármore e branca como a de um morto. (ASSIS, 1992, p. 815).

[...] tão aceita anda a superstição popular que o tem por lobisomem ou quando menos amigo íntimo do diabo... ele! o meu bom e compassivo mestre!

[...] Achei-o a almoçar sozinho, como sempre, [...].

[...] o doutor estava como me parecia na maior parte das vezes, conversando de cousas sérias ou frívolas, misturando uma reflexão filosófica com uma pilhéria, uma anedota de rapaz com uma citação de Virgílio. (ASSIS, 1992, p. 817).

[...] Era medo, não do esqueleto, mas do dono da casa, que se me afigurava ser um homem mau ou um homem doudo. [...]. (ASSIS, 1992, p. 820).

Observa-se que essa caracterização de Dr. Belém se aproxima da deformidade cômica que, para Bergson (1983), exibe uma caricatura por mesclar o cômico e o apavorante. Além disso, tenta unir Apolo e Dioniso, pois Dr. Belém, ao mesmo tempo em que reflete sobre os valores correntes na sociedade com assustadora frieza, parece regredir ao estágio selvagem que os nega, por exemplo, na apresentação do esqueleto a Alberto:

- É minha mulher, disse o Dr. Belém sorrindo. É bonita, não lhe parece? Está na espinha, como vê. De tanta beleza, de tanta graça, de tanta maravilha que me encantaram outrora, que a tantos mais encantaram, que lhe resta hoje? Veja, meu jovem amigo; tal é última expressão do gênero humano. (ASSIS, 1992, p. 816).

E ainda na justificativa do ato de conservar o esqueleto: 
- O medo dos mortos, disse ele, não é só uma fraqueza, é um insulto, uma perversidade do coração. Pela minha parte dou-me melhor com os defuntos do que com os vivos.

[...] Que há entretanto neste esqueleto, que possa meter medo? Não lhes digo que seja bonito; não é bonito segundo a vida, mas é formosíssimo segundo a morte. Lembrem-se que isto somos nós também; nós temos de mais um pouco de carne. (ASSIS, 1992, p. 822).

- É simples, continuou ele; é para que minha segunda mulher esteja sempre ao pé da minha vítima, a fim de que se não esqueça nunca dos seus deveres, porque, então como sempre, é mui provável que eu não procure apurar a verdade; farei justiça por minhas mãos. (ASSIS, 1992, p. 823).

Molino (1980) menciona, de acordo com R. Otto, que no fantástico se resgata a ambivalência: o mysterium tremendum causa o terror e o horror, e o fascinans atrai e seduz. Nessa perspectiva, Dr. Belém reúne a admiração e a repulsa de Alberto, reúne o assassino ciumento que amedronta e o sábio louco que impressiona. Vax (1987), ao comentar a pessoa do assassino ou do sábio perverso, explica que este somente é fantástico no interior do campo que atrela o motivo, objeto que ameaça, e a vítima, sujeito ameaçado. No conto, Dr. Belém ameaça e o sujeito ameaçado é no início D. Marcelina e, posteriormente, ela e Alberto, vítimas de uma mentira de adultério arquitetada pelo Tenente Soares.

Ao considerar que o "fantástico alimenta-se do escândalo da razão” (VAX, 1974, p. 40), convém salientar que a casa de Dr. Belém contribui para a instauração do mistério, onde se desenrola a maioria dos episódios da narrativa de Alberto. O desfecho da suposta história, que culmina com o desaparecimento do Dr. juntamente com o esqueleto, por sua vez, ocorre na floresta, estado selvagem e desconhecido por excelência. No entanto, o mistério não se concentra no ambiente que envolve as personagens, em Machado “o reino maravilhoso está dentro das mesmas”. (DIXON, 1992, p.11).

Com base em O riso de Bergson, Vax (1987) propõe uma aproximação entre o cômico e o fantástico. Da mesma forma que a repetição é um elemento gerador do riso, Vax considera-a também importante para o fantástico quando há o retorno das mesmas situações que testemunham uma obstinação do destino nas tragédias. Isso ocorre no relato de que o Dr. Belém novamente acreditava ser traído por sua esposa, D. Marcelina, sugerindo com a acusação injusta de adultério que ela seria punida com a morte assim como a esposa anterior, Luísa. Em outros termos, o narrador Alberto aventa que a situação de Dr. Belém e D. Marcelina traria o espelhamento da situação de Dr. Belém e Luísa.

Vax (1987) ainda esclarece que o fantástico existe na insegurança e requer a participação. Dessa maneira, tanto os convivas quanto o leitor são envolvidos na aventura do narrador e herói-vítima, Alberto. No desfecho do conto, quando o narrador anuncia ao público 
que o Dr. Belém não existiu, todos se tornam libertos, estabelecendo-se o cômico uma vez que surge a segurança. Alberto, de herói-vítima desvenda-se manipulador, traz o seu riso e o sobressalto de todos que se descobrem enganados por uma farsa. Portanto, o fantástico se desfaz quando o pavor ou o medo acaba, dando lugar à consciência do lúdico feito pelo narrador, ocorrendo a distensão.

O sentimento de uma discordância provoca o cômico e "quando se ri duma história de terror é porque o terror se dissipa” (VAX, 1974, p. 20). No conto, cria-se um parentesco entre o riso e o medo, o chamado humor macabro ou humor perverso, visto que o narrador realiza uma descrição das perturbações mentais do Dr. Belém e seus efeitos em quem o rodeava, busca horrificar criando uma narrativa e divertir-se com o medo dos convivas.

Por produzir o riso, “Um esqueleto” pode ser considerado uma narrativa fantástica falha cuja percepção depende do interlocutor, ou a chamada narrativa fantástica mitigada, segundo Fernandes (2003), em que o equilíbrio inicial retorna com a consciência da personagem. Se, por um lado, para Fernandes (2003), os fenômenos narrados são justificados no espaço onírico e o fantástico opera no plano inconsciente entre a vigília e o sono; por outro lado, neste conto pode-se afirmar que os fenômenos narrados são justificados no espaço literário e o sentimento de estranho opera no plano metalinguístico.

Depreende-se isso porque, conforme já foi dito, de acordo com Todorov (1975), pertencem ao estranho as obras que relatam acontecimentos extraordinários e explicados pela lei da razão. Somente no desenlace de "Um esqueleto", obtém-se uma explicação lógica ao insólito quando se conhece que Dr. Belém é uma construção artística do narrador Alberto graças à técnica do fingimento literário, induzindo o leitor à surpresa por meio do esclarecimento da dúvida e da hesitação, algo próprio do estranho.

\section{A técnica do fingimento literário}

Pode-se verificar que, no conto "Um esqueleto", o acontecimento estranho parece emergir das memórias de Alberto, conferindo familiaridade e crédito à narração. Pretende-se criar nos convivas e no leitor um sentimento estranho a partir da curiosidade em torno da caótica personagem Dr. Belém, especialmente, descobrir se seu comportamento se aproximava mais da racionalidade ou da insanidade. Vale destacar que um dos temas principais da obra machadiana é “o problema dos limites da razão e da loucura”, impossíveis de serem estabelecidos. (CANDIDO, 1995, p. 28). 
A narração feita por Alberto remete a um dos aspectos estruturais das narrativas fantásticas apontados por Todorov (1975) no nível da enunciação, a saber: o emprego de narrador em primeira pessoa para evidenciar a ambiguidade ao mesmo tempo em que o leitor não desconfia de sua autoridade. A hesitação, alvo de críticas à teoria todoroviana, deve ser mantida até o desfecho, todavia, no desfecho do conto analisado, estabelece-se a ordem do possível, o fato insólito recebe uma explicação lógica. Desse modo, sabe-se que a história do esqueleto emerge não da memória, mas da imaginação de Alberto, gerando a surpresa final. O leitor, que se identificava com o herói e vivenciava o inquietante com ele (MOLINO, 1980), constata que se trata de uma ficção dentro da ficção. Lê-se o seguinte na parte final do conto:

\footnotetext{
- Ele doudo? disse Alberto. Um doudo seria efetivamente se porventura esse homem tivesse existido. Mas o Dr. Belém não existiu nunca, eu quis apenas fazer apetite para tomar chá. Mandem vir o chá.

É inútil dizer o efeito desta declaração. (ASSIS, 1992, p. 826).
}

Mediante a atividade metalinguística, opõem-se os “deslimites” da lógica da criação artística em relação à incrível história do Dr. Belém, mesclando lúdico, ironia e humor. A respeito da autorreferencialidade, Dixon (1992) considera-a como um comportamento antirealista que orienta a organização dos contos machadianos. Não restrito ao referencial, o conto "Um esqueleto" oferece um espaço para o mistério, visto que traz a aparência versus a essência, a loucura versus a lucidez. Diante disso, é oportuna a consideração de que, para Machado de Assis, “o 'mundo`onde há 'muita cousa maravilhosa`é a alma” (DIXON, 1992, p. 11) e as falas atribuídas a Dr. Belém prestam-se para comprovar tal afirmação:

- Veste-me como quiseres, dizia ele à mulher; o que não poderás fazer nunca é mudar-me a alma. Isso nunca. (ASSIS, 1992, p. 819).

- [...]. Eu também creio na alma; não creio só, demonstro-a, o que não é para todos. [...] (ASSIS, 1992, p.822).

Ao revelar as contradições da alma, prevalece o "sentimento profundo da relatividade total dos atos, da impossibilidade de os conceituar adequadamente” (CANDIDO, 1995, p. 33). Nessa perspectiva, Piza (2006) apresenta Machado como o escritor que percebe sutilezas e satiriza fraquezas da natureza humana, reage à hipocrisia e vícios presentes nas inclinações do ser social, carregando o texto de densidade filosófica por interpretar temas essenciais da condição humana, expressos de maneira galhofeira, bem como critica a credulidade depositada em crenças espiritualistas e cria uma obra preocupada com a liberdade do indivíduo. 
Piza (2006, p. 198) escreve: "Machado ria muito dessas associações entre corpo e espírito; não acreditava no dualismo, na separação cartesiana entre um e outro, e tampouco no monismo ou no positivismo, que pregavam uma unidade harmônica entre esses dois contrários”. Inclusive, em A nova geração, Machado recomenda o não pedantismo cientificista e deseja a renovação vista em textos de humor e de efeitos cômicos.

Com efeito, depois de dissolvida a angústia gerada pela experiência do manipulador Alberto, o primeiro narrador (N1) sugere se deleitar com a reação de todos os ouvintes, omite os detalhes, deixando incertos os efeitos da descoberta, por exemplo, não se pode afirmar se os rapazes reagem com perplexidade ou com euforia. Importa, sobretudo, a manifestação da ironia que, segundo Candido (1995), é uma ironia fina por conjugar ao mesmo tempo delicadeza e força. Isso faz lembrar ainda o comentário feito pelo referido crítico de que Machado descobre o mundo da alma, ri da sociedade, expõe a esquisitice da personalidade, com um tom humorístico e acadêmico, oferece surpresas ao leitor. Trata-se de uma técnica de espectador que compõe o chamado tom machadiano: "Estilo que mantém uma espécie de imparcialidade que é a marca pessoal de Machado, fazendo parecer duplamente intensos os casos estranhos que apresenta com moderação despreocupada” (CANDIDO, 1995, p. 26-27).

Por meio de ironia, instaura-se a paródia, procedimento intertextual em que se acentuam as diferenças em relação ao modelo, isto é, aproxima-se para se afastar buscando o distanciamento crítico (HUTCHEON, 1985). “Na literatura brasileira, é a partir de Machado de Assis que se observa o aparecimento sistemático da ironia e da paródia como princípios de composição” (BRAYNER, 1979, p. 103). Cria-se a oportunidade para o interlocutor, que deve complementar a história, confirmando a estrutura comunicativa do texto artístico.

Além de francófilo, Machado estudava alemão, era leitor e tradutor de Edgar Allan Poe (PIZA, 2006). Assim como este, o escritor brasileiro manifesta sua visão crítica na produção ficcional, uma vez que a atividade metalinguística se justifica pelo fato de que o criador/escritor tem domínio sobre sua criação/obra, contradizendo os princípios românticos da inspiração. A filosofia da composição direciona sua atenção ao leitor porque o autor busca despertar um determinado efeito e, para isso, escolhe os procedimentos e os recursos necessários (POE, 1997).

Notadamente, na evocação a Ernst Theodor Amadeus Hoffmann como a ambientação do enredo, “Estava-se em pleno Hoffmann” (ASSIS, 1992, p. 815), e no enunciado marcado pela referência a Fausto, Machado recorre à literatura romântica, parodiando e satirizando-a ao inserir a figura do narrador/criador, Alberto, com o intuito de dessacralizar o mito da 
criação ao seu leitor que não mais deve contemplar a obra de arte como inspirada, reconsiderando os processos de representação.

No que tange à evocação de Hoffmann, é necessário recordar, segundo Molino (1980), que a instauração do fantástico como gênero literário ocorre em França com Le diable amoureux (Diabo amoroso), de Jacques Cazotte, mas se consolidam como modelo os contos do referido escritor alemão, nos quais o medo se repete de um sentimento de fascinação e o sobrenatural tem um papel fundamental (STEINMETZ, 2003), triunfando tal modo literário no período de 1830 a 1833, ele se torna o fundador do conto fantástico moderno.

Segundo Paes (1985), a moderna ficção fantástica expõe o irracional e o sobrenatural que são herdados do Medievo e a descrença racionalista, cuja síntese é a dúvida permanente. Mormente, em Hoffmann, há a atmosfera de mistério gerada no gosto pela noite e a apresentação de personagens anormais em que se manifesta a força irracional, pois exibe "um jogo irônico por dúplice e ambíguo, entre racionalidade e irracionalidade” (PAES, 1985, p. 10). Jogo irônico que também aparece neste conto de Machado.

Além disso, conforme Carpeaux (1978), Hoffmann expõe o exagero, repetições e sensacionalismo como estilo narrativo que conduz o horror à produção de efeitos humorísticos, muitas vezes sarcásticos, por exemplo, no desfecho de sua narrativa “A casa deserta”, tem-se uma explicação para os fatos relatados que destrói o efeito fantástico pretendido por Todorov. Em consonância, os efeitos humorísticos e até sarcásticos, bem como o final explicativo também são expedientes utilizados em “Um esqueleto”.

Quanto à menção à leitura de Fausto no conto machadiano, sugere-se o pacto diabólico por se centrar em Mefistófeles, associando-o a Dr. Belém:

O doutor estava como sempre. Líamos então e comentávamos à nossa maneira o Fausto. Nesse dia pareceu-me o Dr. Belém mais perspicaz e engenhoso que nunca. Notei, entretanto, uma singular pretensão: um desejo de se parecer com Mefistófeles.

$[\ldots]$

- Aproveita-se da opinião de excêntrico para me fazer crer que é o diabo... (ASSIS, 1992, p. 819- 820).

Em oposição ao comentário de Alberto, Dr. Belém esclarece: “- Ilude-se meu amigo, quando me atribui semelhante ideia, do mesmo modo que se engana quando supõe que Mefistófeles é isso que diz”. (ASSIS, 1992, p. 820). Diante disso, apesar de não trazer explícito o nome Goethe, provavelmente, seja deste autor o tratamento dado à lenda faustiana ao qual o conto se refere. Por essa razão, pode-se recorrer a Watt (1997) que aponta, entre outras informações, Mefistófeles como um espírito que ensina o significado de viver na Parte 
I da obra goetheana, escrita entre 1788 e 1790. Já na Parte II, escrita após 70 anos, entre 1825 e 1831, com publicação póstuma em 1832, Mefistófeles deseja levar Fausto a se preocupar com a morte e preparar a alma para a eternidade, “é sempre cômico e cínico” (WATT, 1997, p. 201).

Embora identifique para o receptor as citações (Hoffmann e Fausto) com as quais "Um esqueleto” realiza exercícios intertextuais, afirma-se que Machado parodia e satiriza a literatura romântica porque sugere e critica a insuficiência dos padrões estéticos de expressão como o ideal romântico da força inspiradora e a exaltação do amor. Cita-se a antecipação do casamento de Dr. Belém e D. Marcelina, fenômeno inexplicável pelas leis da natureza, que beira o inverossímil, porém provoca a crença no episódio sobrenatural sem explicação racional para o mesmo. E, em torno do casamento, nas palavras de Dr. Belém marcadas pelo contraditório, verifica-se sua definição de amor e uma profecia macabra:

- Não insisto, disse ele, nem faço aqui uma cena dramática. Eu amo-a deveras, mas é um amor de filósofo, um amor como eu entendo que deviam ser todos. [...].

[...]

- De fato, gosto da noiva, disse ele com ar sério; é possível que eu morra antes dela; mas o mais provável é que ela morra primeiro. Nesse caso, juro desde já que irá o seu esqueleto fazer companhia ao outro. (ASSIS, 1992, p.818- 819).

Além disso, Dr. Belém justifica seu crime cometido no passado:

- É verdade, um crime de que fui autor. Minha mulher era muito amada de seu marido; não admira, eu sou todo coração. Um dia porém, suspeitei que me houvesse traído; vieram dizer-me que um moço da vizinhança era seu amante. Algumas aparências me enganaram. Um dia declarei-lhe que sabia tudo, e que ia puni-la do que me havia feito. Luísa caiu-me aos pés banhada em lágrimas protestando pela sua inocência. Eu estava cego; matei-a. (ASSIS, 1992, p. 823, grifo nosso).

Notadamente, Machado conhece as normas tradicionais da narrativa literária e se mostra consciente de que as está infringindo, pois cria o jogo com as convenções estéticas. Ele se serve do jogo de engano apresentado pelo narrador Alberto, voz enunciadora, que se posiciona como aquele que tem uma “verdade” a revelar, assume a categoria de uma autoridade e elabora sua construção, Dr. Belém. Como esclarece Duarte (1994), a linguagem serve ao exercício do poder, ao fingimento, intenção retórica de dominação, exerce a sedução do leitor. Entretanto, “a literatura ultrapassa muitas vezes [...] esse estágio de luta pelo poder e penetra no campo do humor, confessando-se artifício lúdico de comunicação” (DUARTE, 1994, p. 70).

No plano da linguagem do conto, então, observa-se que há o desdobramento da voz do narrador em sujeito do enunciado, envolvido e surpreendido por Dr. Belém, e a que exibe ao 
leitor os artifícios empregados na construção da história, instaurando o humor. “O humor terá como base, assim, essencialmente, um astucioso jogo de linguagem apresentado em dois níveis: o da armadilha lúdica e o da sua explicitação” (DUARTE, 1994, p. 73). Cabe ao receptor do dito humorístico, ser envolvido pela armadilha mas ainda percebê-la e apreciá-la. Assim como Bastos (2003) apontou em “A causa secreta”, conto de Várias Histórias (1885), por exemplo, pode-se mencionar que, no desfecho de "Um esqueleto", ocorre uma armadilha para o leitor experimentar um certo gozo dos convivas, tornando-o cúmplice da mentira literária.

Acerca da mentira, Propp (1992, p. 115) explica: “A mentira enganadora nem sempre é cômica. Para sê-lo, tal como os outros vícios humanos, ela deve ser de pequena monta e não levar a consequências trágicas. Além disso ela deve ser desmascarada. A que não o for não pode ser cômica”. Em “Um esqueleto”, o desmascaramento é feito pelo próprio narrador Alberto com uma atitude consciente, autodesmascaramento voluntário. A partir do desmascaramento, pode ocorrer o riso. No entanto, como já foi dito, N1 não oferece detalhes sobre a emoção dos ouvintes, deixa-a em suspenso, o que gera a ambiguidade tão própria dos textos de Machado e também implica na necessidade de co-participação do leitor.

Consciente de que há na linguagem a potencialidade de mentira, pode-se destacar que uma das estratégias empregadas, assim como a ironia, é o humor. Este, por sua vez, pode ser identificado com a auto-ironia, pois se trata de uma "ironia em que o objeto é o próprio eu que enuncia, ou a ele se refere”. (DUARTE, 1994, p. 66). O humor permite que o homem se ria de si mesmo e do que se relaciona, tem-se o humorismo quando se reflete sobre uma situação cômica na tentativa de entendê-la (ECO, 1989).

Instaura-se o humor, no conto machadiano, quando ocorre a ruptura das expectativas normais com o incidente que consiste na explicitação do fingimento literário. Além de o texto empregar a representação, estabelece ligações com o receptor, bem como exibe os artifícios utilizados na sua realização elucidando o exercício de linguagem. Em outros termos, o jogo literário revela seu caráter de arte.

\section{Considerações finais}

A reflexão acerca da literatura fundada no insólito, no inquietante, no sobrenatural, no estranho, no maravilhoso, no fantástico permite considerá-la um gênero que flui no decorrer da história literária, apresentando-se em novas configurações por buscar diversas formas de 
expressão e diversos conteúdos. Exemplo disso é o conto "Um esqueleto", de Machado de Assis, que, na segunda metade do século XIX, emprega o estranho com o propósito de explicitar o fingimento literário e vice-versa, servindo-se de recursos como o lúdico, a ironia e o humor.

Na leitura de tal texto, exige-se um leitor que se desdobre em dois rumos: primeiro, na direção da narrativa de Dr. Belém, personagem cujas atitudes extravagantes sobrepujam o medo da figura do esqueleto e permitem uma abordagem da contraditória psicologia humana, sempre marcada pelo conflito entre os limites do consciente e do inconsciente, lucidez e loucura, experimentando situações que escapam do conhecido ou do conhecível; segundo, deve-se voltar para a construção do texto literário por depreender o caráter metalinguístico que, sobretudo, desvela a presença mediadora do contador Alberto, narrador-personagem cujo discurso se organiza para conferir abertura à imaginação e ao experimentalismo da criação ficcional, bem como provocar a credibilidade e a co-participação do receptor.

Por fim, o modo como se constitui o conto de Machado de Assis evidencia que sua intencionalidade preza pela concretização da arte. Sobretudo, devido a explorar o espaço imaginário, manifesta sua singularidade ao instaurar o jogo que transita do foco do sujeito para o autorreferencial e propositadamente conduz o leitor ao imprevisto, dando provas da modernidade machadiana.

\section{Referências}

BASTOS, Simíramis. D. T. Machado de Assis e o fantástico. Revista Risco, São Miguel do Oeste: UNOESC, ano 3, n. 5, p. 32-35, jan/abr., 2003.

BERGSON, Henri. O riso. 2. ed. Tradução Nathanael C. Caixeiro. Rio de Janeiro: Zahar, 1983.

BRAYNER, Sônia. O labirinto do espaço romanesco. Rio de Janeiro: Civilização Brasileira, 1979.

CANDIDO, Antonio. Esquema de Machado de Assis. Vários Escritos. 3. ed. rev.amp. São Paulo: Duas Cidades, 1995. p. 17- 39.

CARPEAUX, Otto Maria. Prosa e ficção do romantismo. GUINSBURG, J. (Org.). O romantismo. São Paulo: Perspectiva, 1978.

COSTA VAL, Ana Cristina Pimenta da. Machado de Assis e o fantástico espelho. Revista Scripta, Belo Horizonte, v. 3, n. 6, p. 20-29, 2000. 
DIXON, Paul. Os contos de Machado de Assis: mais do que sonha a Filosofia. Porto Alegre: Movimento, 1992.

DUARTE, Lélia Parreira. Ironia, humor e fingimento literário. Resultados da pesquisa sobre ironia e humor na Literatura, Belo Horizonte, n. 15, p. 54-78, fev. 1994.

ECO, Umberto. Sobre os espelhos e outros ensaios. 3. ed. Rio de Janeiro: Nova Fronteira, 1989.

FERNANDES, Marcelo J. Machado de Assis quase-macabro. Poiésis, n. 85, abr. 2003. Disponível em<http://www.netterra.com.br/poiesis/85/machado_de_assis.htm>. Acesso em 15 set. 2006.

HUTCHEON, Linda. Uma teoria da paródia. Rio de Janeiro: Edições 70, 1985.

MACHADO DE ASSIS. Um esqueleto. Obra Completa. Rio de Janeiro: Nova Aguilar, 1992, v. 2. p. 814-826.

MOLINO, Jean. Trois modèles d’analyse du fantastique. Europe Revue Littéraire Mensuelle, Paris , n. 611, mar. 1980.

PAES, José Paulo. Introdução. Os buracos da máscara: antologia de contos fantásticos. São Paulo: Brasiliense, 1985. p. 7-17.

PIZA, Daniel. Machado de Assis: um gênio brasileiro. 2. ed. São Paulo: Imprensa Oficial, 2006.

POE, Edgar. A. “A filosofia da composição”. Ficção completa, poesia \& ensaios. MENDES, O. (Org. e Tradução). Colaboração Milton Amado. Rio de Janeiro: Nova Aguilar, 1997, p. 911- 920.

PROPP, Vladimir. A mentira. Comicidade e Riso. Tradução de Aurora F. Bernadini e Homero F. de Andrade. São Paulo: Ática, 1992. p. 115-118.

STEINMETZ, Jean-Luc. La Littérature fantastique. 4. ed. Paris: PUF, 2003.

TODOROV, Tzvetan. Introdução à literatura fantástica. São Paulo: Perspectiva, 1975.

VAX, Louis. A arte e a literatura fantásticas. Tradução João Costa. Lisboa: Arcádia, 1974.

La séduction de I'étrange: Étude sur la littérature fantastique. Paris: Presses Universitaires de France, 1987 (Quadrige).

WATT, Ian P. A apoteose romântica dos mitos renascentistas. Mitos do individualismo moderno: Fausto, Dom Quixote, Dom Juan, Robinson Crusoé. Tradução Mario Pontes. Rio de Janeiro: J. Zahar, 1997. p. 196-227. 